\title{
MENYOAL KESENJANGAN ANTARA DAS SOLLEN ISLAM DENGAN DAS SEIN PRAKSIS KEHIDUPAN KAUM MUSLIMIN
}

\author{
Yusuf Suyono \\ Institut Agama Islam Negeri (IAIN) Walisongo \\ e-mail:yusuf.suyono@yahoo.co.id
}

\begin{abstract}
This paper embarks from the question why the valuable Islamic ethics cannot be ethos grounded in the nationstate Muslim majority country-including in Indonesia? Phenomena such as the majlis taklim, majlis dhikr, interest pilgrimage exceeds the quota, the Islamic banking activity is equally excited, is real. However, it is not enough. Muslims should master the science, economics, and the strategic role of national politics. Islamic ethics is Das sollen, the Muslims condition is Das Sein. Prophet Muhammad has abled to unite Das sein and Das sollen in his life, because Islam has become his blood so that he is a mirror and store front of Islam par excellence. Muslims, as his follower, not been able to do like him. Al-Amir Arsalan Syākib, Muhammad 'Abduh, Mohammad Iqbal, Muhammad al-Ghazālī, Hassan Hanafi have tried to formulate how to bridge the gap between Das sollen and Das Sein for Muslims. They have a deep concern about the wide gap between Das Sein praxis in life of Muslims with Das sollen Islamic teachings in slogan ya'lu wala yu'la 'alaih. While at the same time they see how the beruf ethos of Calvinism could encourage the ethos of modern capitalism to its adherent sin Western Europe, a Zen Buddhist ethos could push the Japanese into the Asian tigers, and spirit Confucius encourage the Korean people into the Asian dragon.
\end{abstract}

\begin{abstract}
Abstrak:Tulisan ini berangkat dari pertanyaan mengapa etika Islam yang adiluhung itu tidak bisa membumi menjadi etos bangsa di negara-negara yang mayoritas penduduknya Muslim-termasuk di Indonesia. Fenomena seperti majlis taklim, majlis zikir, minat menunaikan ibadah haji melebihi kuota, aktivitas perbankan syariah tak kalah bersemangat, adalah nyata. Namun, itu tidak cukup. Umat Islam seharusnya lebih dari itu dalam penguasaan ilmu pengetahuan, ekonomi, dan peran strategis politik kebangsaan. Etika Islam itulah Das Sollen, keadaan kaum Muslimin itulah Das Sein. Muhammad
\end{abstract}


YUSUF SUYONO: Menyoal Kesenjangan ...

Rasulullah telah mampu menyatukan Das Sein dan Das Sollen dalam hidupnya. Hal itu dikarenakan Islam telah menjadi darahnya sehingga beliau adalah cermin dan etalase Islam par excellence. Kaum Muslimin, sebagai pengikutnya, belum mampu berbuat seperti uswah mereka itu. Al-Amir Syakib Arsalan, Muhammad Abduh, Mohammad Iqbal, Muhammad alGhazali, Hassan Hanafi telah berusaha menformulasikan bagaimana menjembatani jurang pemisah antara Das Sollen dan Das Sein kaum Muslimin itu. Semuanya itu karena didorong oleh keprihatinan melihat betapa dalam dan menganganya jurang antara Das Sein praksis kehidupan Umat Islam dengan Das Sollen ajaran Islam yang ya'lu wa lā yu'lā 'alaih itu. Sementara di saat yang bersamaan mereka melihat betapa etos beruf Calvinisme bisa mendorong etos Kapitalisme modern bagi pemeluknya di Eropa Barat, etos Buddha Zen bisa mendorong bangsa Jepang menjadi macan Asia, dan spirit Konfucian (Kong $\mathrm{Hu} \mathrm{Cu}$ ) mendorong bangsa Korea menjadi dragon Asia.

Keywords:filsafat Islam, dialektika sirkular, etika Islam, filsafat Iqra', Das Sollen, dan Das Sein.

\section{A. Pendahuluan}

Filsafat Islam -kata majemuk yang terdiri dari kata Filsafat dan Islam telah banyak didefinisikan. Kata Islam berposisi sebagai sifat/adjective/na'at dari kata Filsafat. Secara demikian, Filsafat Islam adalah berpikir bebas, radikal, dan berada pada taraf makna, yang bercorak Islami. ${ }^{1}$ Kata bebas, dimaksudkan dapat memilih apa saja untuk dipikirkan. Kata radikal dari kata radix artinya akar. Berpikir radikal berarti berpikir sampai ke akar suatu masalah, mendalam sampai ke akar-akarnya melampaui fisik dan memasuki wilayah metafisis, sehingga intuisipun adalah salah satu jenis berpikir radikal. Bergson, "Intuition is only a higher kind of intellect". Berpikir dalam makna adalah mencari makna dari sesuatu, atau keberadaan dan kehadiran sesuatu itu. Bercorak Islami adalah bahwa berpikir bebas, radikal, dan berada dalam taraf makna tersebut adalah dalam sinar petunjuk Islam (in the light of Islam).

TEOLOGIA, VOLUME 25, NOMOR 1, JANUARI-JUNI 2014 
YUSUF SUYONO: Menyoal Kesenjangan ...

Pemikiran adalah tanda kehidupan manusia, natur-nya seperti air yang terus mengalir.Tidak ada sesuatupun yang betul-betul berada, sebab semuanya serba menjadi (state of becaoming). Segala sesuatu berlalu dan tiada sesuatu yang tetap. Manusia adalah makhuk berpikir. Selama dia masih hidup akan selalu berpikir. Dengan demikian,adanya rekonstruksi pemikiran adalah hal yang lumrah dalam dunia permikiran filsafati bahkan dunia ilmu pengetahuan. "It must, however, be remembered that there is no such thing as finality in philosophical thinking", kata Muhammad Iqbal. ${ }^{3}$ Dan hal itu diawali dengan kegemaran bertanya. Temasuk bertanya tentang jawaban dari pertanyaan sebelumnya. Sejak ribuan tahun yang lalu, sampai kapanpun bertanya akan tetap terbuka seperti tergambar dalam sajak kuno berikut ini: ${ }^{4}$

Aku datang-entah dari mana

Aku ini- entah siapa

Aku pergi-entah ke mana

Aku akan mati-entah kapan

Aku heran bahwa aku bergembira

Dialektika sirkular pertanyaan dan jawaban adalah paralel dengan realitas ayam dan telur. Pertanyaan, sebagai tesis, harus mendatangkan jawaban, sebagai anti-tesis. Dan jawaban tersebut harus pada gilirannya menjadi tesis baru yang mengundang jawaban baru sebagai sintesis, dan sintesis ini harus juga menjadi tesis baru lagi. Dan begitulah seterusnya, sehingga dunia pemikiran itu terus bergulir sebagai kegiatan yang "never ending process" (proses yang tidak pernah berakhir).

\section{B. Das Sein Praksis Kehidupan Muslim}

Pertanyaan krusial terus-menerus menjadi pertanyaan adalah mengapa etika Islam yang adiluhung itu tidak bisa membumi 
YUSUF SUYONO: Menyoal Kesenjangan ...

menjadi etos bangsa di negara-negara yang mayoritas penduduknya Muslim-termasuk di Indonesia. Sekali lagi mengapa? Umat Islam seharusnya punya potensi luar biasa. Kini terdapat sekitar 1,7 miliar penduduk Muslim di seluruh dunia, sekitar 240 juta di antaranya berada di Inonesia. Di Negara kita, semarak dan semangat beragama dalam beragam bentuknya sangat menonjol. Khusus untuk kegiatankegiatan ritual keislaman seperti majlis taklim, majlis dzikir, pengajian-pengajian, dan aktivitas yang memperkokoh keimanan memang tergolong spektakuler. Minat menunaikan ibadah haji melebihi kuota sehingga harus inden beberapa tahun. Konpensasinya ibadah umrah nyaris menjadi ibadah harian atau mingguan secara bergelombang. Aktifitas perbankan syariah atau sejenisnya juga tak kalah bersemangat. Belum terhitung berbagai upacara social keagamaan yang terkait dengan peringatanperingatan hari-hari besar umat Islam. Negeri kita ini boleh dikatakan tidak kehilangan siprit dan daya kreatif Islam yang memberi warna pada keIndonesiaan. KeIslaman dan keIndonesiaan menyatu dalam aroma yang kental, walaupun tetap lentur dan tidak kehilangan rasa nasionalitasnya yang relijius.

Namun demikian, Umat Islam tidak cukup berhenti di titik ritual-simbolik seperti itu saja. Mereka harus bergerak maju dengan kekuatan strategis dalam penguasaan ilmu pengetahuan, ekonomi, dan peran strategis politik kebangsaan. Di tiga aspek ini, Umat Islam Indonesia masih lemah dan tidak menentukan, kecuali sebatas partisipan. Di bidang ekonomi, kalau dilihat dari satu aspek saja, sebagai contoh, kepemilikan modal, maka para pemilik modal skala besar di negara kita mayoritasnya adalah bukan Muslim. Lihat daftar 10 orang terkaya di Indonesia berikut ini:

1. R. Budi dan Michel Hartono (Djarum, BCA): 15 miliar dollar AS (Rp. 175,5 triliun),

2. Keluarga Eka Tjipta Wudjaja (Grup Sinarmas): 7 miliar dollar AS (Rp.175,5 triliun),

TEOLOGIA, VOLUME 25, NOMOR 1, JANUARI-JUNI 2014 
YUSUF SUYONO: Menyoal Kesenjangan ...

3. Keluarga Anthoni Salim (Grup Salim): 6,3 miliar dollar AS (Rp. 73,71 triliun),

4. Keluarga Susilo Wonowidjojo (Gudang Garam): 5,3 miliar dollar AS (Rp. 62 triliun),

5. Chairul Tanjung (CT Corp): 4 miliar dollar AS (Rp. 46, 8 triliun),

6. Sri Prakash Lohia (Indorama): 3,7 miliar dollar AS (Rp. 43, 29 triliun),

7. Keluarga Boenjamin Setiawan (Kalbe Farma): 3 miliar dollar AS (Rp. 35,1 triliun),

8. Peter Sondakh (Grup Rajawali): 2,7 miliar dollar AS (Rp. 31,59 triliun),

9. Keluarga Mochtar Riady (Grup Lippo): 2,5 miliar dollar AS (Rp 29,25 triliun),

10. Sukanto Tanoto (Grup Raja Garuda Mas): 2,3 miliar dollar AS (Rp. 26,91 triliun). ${ }^{5}$

Dari daftar orang terkaya tersebut, kita juga lihat bahwa hanya segelintir umat Islam yang masuk dalam kategori orang paling kaya di Indonesia dan amat jauh jumlahnya manakala dibandingkan umat lain, sebut langsung saja misalnya para pengusaha keturunan Tionghoa, yang mayoritasnya adalah non-Muslim. Sepertinya hanya Choirul tanjung yang Muslim (urutan no. 5), lainnya para Taipang non-Muslim. Umat di bawah masih mayoritas miskin. Kelas menengah meski sedang tumbuh tapi masih belum termanfaatkan potensi ekonominya. Program-progam pengembangan ekonomi selain masih banyak teori dan bicara, juga masih baru menyentuh sisi pinggiran. Belum ada gerakan pemberdayaan ekonomi umat yang bersifat massif, kecuali sebatas verbal dan slogan. Dengan begitu, bukan rahasia umum bahwa ekonomi Indonesia kini dikuasai oleh non-Muslim meski mereka adalah kelompok minoritas, sementara umat Islam yang mayoritas berada pada kondisi 
YUSUF SUYONO: Menyoal Kesenjangan ...

minoritas di bidang kesejahteraan ekonomi. Jadi, dari sisi penguasaan ekonomi kaum minoritas lebih menguasai daripada kaum mayoritas, sehingga dalam aspek ekonomi kaum mayoritas di Indonesia sedang berada dibawah kendali minoritas.

Di bidang politikpun sepertinya tidak jauh berbeda. Politik kepartaian Umat Islam pada perkembangan mutakhirnya mengecewakan. Para elit dan kekuatan partai politik yang dimiliki umat Islam itu terjebak pada pragmatisme dan semata-mata mengejar materi dan kursi bahkan di antaranya malah terjerat korupsi dan skandal. Mereka yang mendapat predikat wakil-wakil rakyat prilakunya belum ideal dengan jargon-jargon yang dilabelkan pada diri mereka saat kampanye seperti "jujur", "amanah", "adil”, "anti korupsi". Hal seperti itu adalah hipokrisi yaitu pecah kongsi antara ucapan dan perbuatan, antara keyakinan dan prilaku, dan antara Islam yang diyakini dengan praksis kehidupannya.

Dalam penguasaan ilmu pengetahuan yang kemudian melahirkan anak kandungnya teknologi, keadaannya juga belum menggembirakan dibandingkan dengan negara-negara yang mayoritasnya berpenduduk non-Muslim. Berikut ini beberapa hal tentang peringkat Indonesia, termasuk bidang pendidikan seperti rangking Perguruan Tinggi, dan mutu pendidikannya, dan sebagainya.

1. untuk bidang kekuatan militer Indonesia peringkat 13. Pada tahun 2013 ini menurut Global Fire Power kekuatan militer indonesia naik menjadi peringkat 13 dunia, dimana sebelumnya pada tahun 2012 hanya peringkat 18 dunia. Indonesia Berhasil Melewati Negara Besar seperti Jepang, Iran, dan Israel. Penilain yang dilakukan oleh Global Fire Power didasarkan beberapa Faktor seperti Jumlah Personnel, Weapon Systems, Naval Power, Logistical dan, Resources (Oil Production, Oil Consumption,Oil Proven Reserves). 
2. Kopassus Indonesia peringkat 3 dunia.

Kopassus adalah pasukan khusus Angkatan Darat Indonesia. kelompok yang melakukan misi operasi khusus bagi pemerintah Indonesia, seperti tindakan langsung: konvensional perang,sabotase,kontra-pemberontakan: kontra-terorisme, dan pengumpulan intelijen. Kopassus ini didirikan pada tanggal 16 April 1952. dan satuan khusus paling ditakuti adalah Den 81 Gultor. sayang satuan ini kurang populer dari pada satuan Densus 88 milik kepolisian di Indonesia, padahal den 81 Gultor adalah salah satu satuan paling ditakuti di dunia. seorang pasukan Den 81 Gultor sama dengan kemampuan 5 tentara biasa. Dalam survey banyak yang bingung mengapa satuan ini masuk dalam daftar top 5 sedangkan satuan amerika tidak masuk. itu semua adalah dari segi penilaian kemampuan pasukannya. Navy Seals boleh saja mengerahkan semua peralatan tempur canggihnya untuk mengatasi suatu peristiwa, tapi Kopassus mendapatkan poin yang sama dengan Navy Seals namun dengan peralatan seadanya dan lebih mengutamakan kemampuan individu pasukan.

3. Olah Raga Bulutangkis peringkat 6

4. Olah Raga Sepak bola peringkat 170

5. Kepulauan peringkat 1 dan Jumlah Penduduk peringkat 4.

6. Kecepatan Internet peringkat 104

Kecepatan internet di Indonesia perlahan tetapi pasti mulai meningkat. Laporan dari perusahaan internet content deliveri, Akamai, yang mengungkap kabar baiktersebut. Setelah sempat menduduki posisi terbawah sebagai negara dengan kecepatan internet rata-rata terendah di wilayah Asia Pasifik, pada kuartal I tahun 2013, Indonesia berhasil melonjak naik mengungguli 
YUSUF SUYONO: Menyoal Kesenjangan ...

tiga Negara Asia lain. Pada laporan yang dikutip dari The Next Web, terungkap bahwa kecepatan rata-rata internet di Indonesia sudah meningkat hingga 1,5 Megabit per detik (Mbps).

7. Serangan Cyber Peringkat 2

8. Pendidikan Peringkat 64.

Menurut Education For All Global Monitoring Report 2012 yang dikeluarkan oleh UNESCO setiap tahunnya, pendidikan Indonesia berada di peringkat ke-64 untuk pendidikan di seluruh dunia dari 120 negara. Data Education Development Index (EDI) Indonesia, pada 2011 Indonesia berada di peringkat ke-69 dari 127 negara. Indonesia terdapat lebih dari 1,8 juta anak tiap tahun tidak dapat melanjutkan pendidikan, disebabkan oleh tiga faktor, yaitu ekonomi, kerja usia dini untuk mendukung keluarga dan pernikahan di usia dini.

9. Pariwisata Peringkat 70 , keindahan alam peringkat 6

10. Universitas Terbaik, UI peringkat 309

Delapan universitas terbaik di Indonesia mengalami penurunan rangking dan bahkan terpuruk di peringkat 800 besar dunia versi QS World Universities Rangkings tahun 2013/2014. Dari data yang dikirim QS World University pada September 2013, Universitas Indonesia (UI) tetap menjadi institusi pendidikan terbaik di tanah air, berada di peringkat 309, UI mengalami penurunan peringkat yakni dari rangking 273. Institut Teknologi Bandung (ITB) yang berada di kisaran peringkat antara 461-470. Hal serupa juga menimpa enam universitas lainnya yakni Universitas Gadjah Mada (UGM), Universitas Airlangga (Unair), Institut Pertanian Bogor (IPB), Universitas Diponegoro (Undip), Institut Teknologi Sepuluh November (ITS), dan Universitas Brawijaya (Unbraw). 
YUSUF SUYONO: Menyoal Kesenjangan ...

Peringkat Unair hingga Unbraw tahun 2013 versi QS World UniversityRangkings ada di atas 701.

11. Negara gagal peringkat 63

12. Index Pembangunan Manusia (IPM) Peringkat 121

13. Olah Raga Catur. Putra peringkat 73, Putri peringkat 24

14. Negara dengan Kota Teramah, Ubud Bali Peringkat 9

15. Supporter fanantik peringkat 3

16. Mamalia dan Spesies terancam punah peringkat 4

17. Infrastruktur peringkat 78

18. Maskapai Penerbanagn. Garuda Indonesia peringkat 8

19. Gaji Presiden tertinggi peringkat $3{ }^{6}$

Dari data tersebut di atas, terlihat di bidang pendidikan keadaannya belum menggembirakan. Sudah bisa ditebak bahwa pada gilirannya penguasaan ilmu pengetahuanpun masih tertinggal dari bangsa-bangsa yang maju. Logika berikutnya adalah bahwa minat baca anak-anak Indonesia juga rendah.

Berdasarkan survei yang dilakukan oleh International Education Achievement (IEA) pada awal tahun 2000 menunjukkan bahwa kualitas membaca anak-anak Indonesia menduduki urutan ke 29 dari 31 negara yang diteliti di Asia, Afrika, Eropa dan Amerika. Dengan demikian tidaklah mengherankan bila Indeks kualitas sumber daya manusia (Human Development Index/HDI) di Indonesia juga rendah.Hal ini sesuai dengan survei yang dilakukan oleh UNDP pada tahun 2005 bahwa HDI Indonesia menempati peringkat 117 dari 175 negara. ${ }^{7}$ Pada hal Das Sollen Islam di bidang ini adalah bahwa perintah pertama Allah kepada Rasul, mestinya juga Umatnya, bukan perintah shalat, puasa, zakat, maupun haji melainkan perintah membaca. QS. al-'Alaq [96]: 1-5:

Bacalah dengan (menyebut) nama Tuhanmu yang menciptakan. Dia telah menciptakan manusia dari segumpal darah. Bacalah, 
YUSUF SUYONO: Menyoal Kesenjangan ...

dan Tuhanmulah yang Maha Pemurah; yang mengajar (manusia) dengan perantaran kalam.Dia mengajar kepada manusia apa yang tidak diketahuinya.

Ayat-ayat pertama surat al-'Alaq ini kemudian melahirkan apa yang disebut filsafat Iqra'. Filsafat Iqra' yang mewacanakan banyak segi dari ilmu pengetahuan, antara lain:

1. Sarana ilmu pengetahuan. Dalam surat al-'Alaq tersebut, kata iqra' merupakan sarana paling utama untuk menggapai ilmu pengetahuan. Namun ada yang perlu dicermati, yaitu kata iqra' yang kata kerja transitif itu (Muta'addiy) tidak memiliki objek (Maf'ūl bihi) pada ayat 1 dan 3 surat al-'Alaq tersebut. Inilah yang kemudian melahirkan apa yang disebut dengan filsafat Iqra'. Tidak disebutkannya objek untuk kata kerja transitif tersebut justru sangat jelas menunjukkan keniscaan Unity of Science (kesatuan ilmu-ilmu). Iqra' di situ bisa diartikan bacalah, tetapi juga bisa telitilah. Objek dari Iqra' yang berarti "bacalah" adalah al-Wahy al-Matluw (wahyu yang terbaca) yaitu al-Qur'an (bacaan atau yang dibaca), sedang Iqra' yang berarti "telitilah" adalah al-Wahy Ghayr al-Matluw (wahyu yang tidak terbaca) yaitu universe (alam semesta) ini. Yang disebut pertama melahirkan ilmu-ilmu yang biasanya disebut alGhazali dengan al-'Ulūm al-Syar'iyah (ilmu-ilmu syari'at/ agama). Dari yang disebut kedua akan melahirkan al-'Ulūm ghayr al-Syar'iyah (ilmu-ilmu umum).

2. Sumber ilmu. Dalam surat al-'Alaq ayat 4 dan 5 ada kata kerja 'allama yang berarti mengajar, atau memberi ilmu. Allahlah yang mengajar manusia bermacam-macam ilmu pengetahuan. Dari situ bisa dipahami bahwa sumber bermacam-macam ilmu adalah Allah. Dengan kata lain, ilmu-ilmu itu bersatu dalam satu titik sumber, yaitu Allah. 
YUSUF SUYONO: Menyoal Kesenjangan ...

Membandingkan potret praksis kehidupan umat Islam sebagai Das Sein dan filsafat Iqra' tersebut sebagai Das Sollen, terlihat dengan jelas kesenjangan yang sangat lebar. Kemudian bandingkan minat baca bangsa Jepang. Kita akan baca pujian orang Barat terhadap minat baca bangsa Jepang "Books are Japanese true lovers " (Buku adalah kekasih sejati bangsa Jepang"). Al-Amir Syākib Arsalan menyebut-nyebut bangsa Jepang sebagai cermin perbandingan dalam karyanya Limāżā Taakhkhar al-Muslimūn wa Limāżāa Taqaddama Ghayruhum dengan sub-bab العبرة للعرب و سائر المسلمين برقي اليابينين (Pelajaran bagi bangsa Arab dan seluruh kaum Muslimin dari kejayaan bangsa Jepang). ${ }^{8}$

\section{Das Sein Potret Muslim di Negara-Negara Arab}

Melihat keadaan Negara-negara Arab yang sedang bergejolak seperti Mesir, Libia, maupun Suriah, teringat oleh kita pepatah yang mengatakan, "Kalah jadi abu, Menang jadi arang." Apa pun alasannya, pertikaian dan perang saudara apalagi seiman hanya akan menghasilkan kebinasaan. Siapa pun pemenangnya hanya akan mendapatkan reruntuhan dan hanya akan hidup bersama luka di atas puing-puing kehancuran.

Dalam setiap prahara yang menimpa Dunia Islam seperti di atas, sering kita tunjuk Zionis Yahudi dan kroni-kroni sebagai dalang dari semua kekacauan ini. Alasannya, sejak zaman Nabi Muhammad, kelompok zionis Yahudi ini sudah terbiasa menjalankan aksinya dengan mengadu domba antar sesame Muslim. Qabilah Aus dan Khazraj terlibat pertikaian berkepanjangan tanpa ujung pangkal. Setiap kali mereka akan berdamai selalu ada masalah kecil yang dikipasi oleh sekelompok kecil orang Yahudi, sehingga kedua kelompok itu bertikai lagi. Konon, mata pencaharian kelompok zionis itu adalah membuat konflik karena dari situ mereka mendapatkan penghasilan yang besar. Namun ketika Nabi Muhammad hijrah ke Madinah, kedua kabilah itu dapat didamaikan dengan tuntas, dan 
YUSUF SUYONO: Menyoal Kesenjangan ...

begitu kedua kabilah itu bisa damai, kelompok zionis banyak yang kehilangan pencahariannya.

Menjadikan zionis sebagai kambing hitam prahara itu juga tidak seluruhnya benar. Menurut Ahmad Syafi'i Ma'arif, sekuat dan secanggih apapun tipu daya kaum zionis untuk mengobarkan perang dan meluluhlantakkan bangsa-bangsa Muslim, upaya itu masih bisa ditangkis jika elit negara-negara Muslim itu masih punya hati nurani untuk tidak saling memakan bangkai saudara seimannya. Mereka membangkang perintah Allah dalam Qur'an sumber ajaran Islam yang seharusnya dipraktekkan.

Mesirkeadaan politiknya juga tidak stabil. Setelah rezim Husni Mubarak tumbang, Mursi dan partai Ikhwanul Muslimin mendapatkan mandat penuh dari rakyat Mesir, namun ternyata juga gagal membangun Mesir. Mursi gagal menstabilkan ekonomi Mesir, sementara Partai Ikhwanul Muslimin juga gagal merangkul dukungan dari partai-partai yang lain, termasuk partai-partai Islam lain, tentunya. Akibatnya, politik Mesir semakin tidak stabil, semua partai Islam yang ada di Mesir larut dalam ego kelompok masingmasing dan melupakan nasib rakyat Mesir yang menderita. Pemerintahan Mursi juga harus kembali dilawan oleh rakyat Mesir yang kecewa dengan tumpukan sampah dan harga bahan pokok yang terus meninggi. Dua hal inilah yang merupakan hal pokok yang gagal dijawab oleh Mursi. Mursi ditumbangkan oleh militer Mesir dan Ikhwaul Muslimin dibubarkan. Mesir yang seperti itu bisa-bisa senasib dengan Indonesiayang terlalu lama menapak masa teransisi ini. Euforia demokrasi yang berlebihan dan tidak dilandasi kedewasaan elite ternyata lebih banyak menghancurkan sebuah peradaban ketimbang memperbaiki keadaan. Sejarah mengajarkan, Yugoslavia yang besar akibat isu demokratisasi berbasis suku dan agama telah memerangkap negara itu dalam perang saudara dan akhirnya tercabik-cabik menjadi negara-negara kecil.

TEOLOGIA, VOLUME 25, NOMOR 1, JANUARI-JUNI 2014 
YUSUF SUYONO: Menyoal Kesenjangan ...

Saat ini isu suku, agama, dan keyakinan juga kembali diterpakan ke Negara-negara Muslim yang sedang dilanda prahara. Konflik demi konflik yang terjadi di dunia Islam kini berubah menjadi semakin mengerikan dengan tebaran fitnah bernuansa konflik antar agama. Suriah, misalnya, berita tentang kekejaman tentara pemerintah Suriah (Bashar al-Asad) yang membunuh secara sadis para ulama Sunni serta membasmi penduduk sipil, termasuk perempuan dan anak-anak, bersamaan itu pula berita tentang kekejaman para tentara pemberontak (diklaim Sunni) ketika membantai para prajurit pemerintah, sungguh memilukan hati. Apalagi yang diserang dan yang menyerang sama-sama memekikkan takbir. Perang saudara di Suria antara pasukan pemerintah dengan pihak oposisi telah menewaskan lebih dari 100 ribu rakyatnya sendiri, hampir semua korban itu adalah Muslim. Hal yang sungguh menikam hati kita Umat Islam. Pihak oposisi dibela oleh Amerika dan sekutunya plus Arab Saudi dan Turki, rezim al-Asad didukung Rusia dan Iran. Drama tragedi yang selain memilukan, dan juga memalukan. Suara sendu munajat kita berbunyai, "Ya, Allah sampai berapa lama lagi Umat Islam ini baku hantam satu sama lain; Untuk berapa lama lagi mereka berkuah darah yang tidak jarang telah menggunakan nama-Mu dalam takbir, ya Allah? kehancuran Suriah, sama artinya dengan lumatnya peninggalnya sejarah masa lalu yang bertebaran di negeri itu, sebagaimana yang diderita Afghanistan dan Irak sebelumnya. "Yang menang jadi arang, yang kalah jadi abu". Itulah gambaran Da Sein praksis kaum Muslimin di Suria. ${ }^{9}$ Das Sollen nya, kedua belah pihak: rezim al-Asaad maupun pihak oposisi samasama siap mengikatkan diri pada perintah Allah, QS. al-Hujurat [49]: 10: "Orang-orang beriman itu sesungguhnya bersaudara. Sebab itu damaikanlah (perbaikilah hubungan) antara kedua saudaramu itu dan takutlah terhadap Allah, supaya kamu mendapat rahmat)."

Menyaksikan Das Sein Umat Islam di atas, maka akan timbul pertanyaan Mengapa Das Sollen Islam Tidak Menyatu Dengan Das Sein Praksis Muslim? Satu pertanyaan yang terus-menerus 
YUSUF SUYONO: Menyoal Kesenjangan ...

menunggu jawaban dari para pemikir dan ilmuwan Muslim hingga lahirnya Umat Islam yang benar-benar menjadi khaira ummah. Pada sisi Das Sollen, semuanya hafal jargon, "Al-Islāmu ya'lū wa lā yu'lā 'alaih", semuanya paham pujin H.A.R. Gibb, "Islam is a complete civilization", semuanya akan mengiyakan, walaupun dengan sedikit catatan, ucapan Betrand Russel-sebagaimana dikutip Ibn Warraq dalam Leaving Islam:

Among religions, Bolshevism (Communism) is to be reckoned with Muhammadanism (Islam) rather than with Christianity and Buddhism. Christianity and Buddhism are primarily personal religions, with mystical doctrines and a love of contemplation. Muhammadanism (Islam) and Bolshevism are practical, social, unspiritual, concerned to win the empire of this world.10

Namun demikian, pada sisi Das Sein Umat Islam belum ada yang berani mengatakan bahwa "Al-Muslimūna ya'lūna wa lā Yu'lā 'alaihim." Itu artinya pecah kongsi antara : Islam dan praktek kaum Muslimin -sebagai pemeluknya; Islam doktrin dan Islam peradaban; normatifitas Islam dan historisitas Islam; Das Sollen Islam sebagai ajaran dan Das Sein Islam pada praktek pemeluknya. Apakah memang Das Sollen dan Das Sein itu ditakdirkan tidak bisa dipersatukan? Jawabannya bisa positif, bisa juga negatif.

Jawaban postif adalah jawaban optimistik bersemangat membumikan Islam. Hal itu diandaikan bisa, karena ada teladan dari diri Rasulullah yang dinyatakan sendiri oleh Allah sebagai rahmatan li al-'âlamīn (QS. al-Anbiyā' [21]: 107: "dan tiadalah Kami mengutus kamu, melainkan untuk menjadi rahmat bagi semesta alam."

Dalam ayat itu ada satu huruf yaitu "كَ" (damīr muttașil li almukhațab) yang bisa dijadikan starting point bagi filsafat " كang tidak hanya seperti Plato dengan idealismenya yang memadukan antara pendapat Herakleitos dan Parmenides, antara entitas yang bisa dikategorikanbeing dan entitas yang bisa dikategorikan becoming; atau seperti Aristoleles dengan rasionalisme yang 
YUSUF SUYONO: Menyoal Kesenjangan ...

memadukan antara form dan matter dengan mengatakan bahwa form lah yang telah merubah matter dari potensialitas menuju aktualitas, yang semuanya bernuansa wacana belaka, karena semua hasil pemikiran para filsof Yunani adalah spekulatif dan non-empirik. Dlamir " ك" dalam ayat itu, adalah sosok Muhammad Rasulullah yang telah mematrikan, tidak hanya memadukan antara form (Das Sollen) Islam dan matter (Das Sein) paraktek Muslim pada diri beliau. Rasulullah adalah Islam dan Muslim sekaligus. Pemisahan antara Islam dan Muslim pada diri beliau adalah suatu kemustahilan. Rasulullah adalah etalase Islam par-excellence. Adalah tidak mengherankan ketika istri beliau ditanya tentang akhlak beliau, jawabannya adalah "kāna khuluquhu al-Qur'ān". Artinya, Islam dan kemusliman; akhlak Islam dan Muslim; Das Sollen Islam dan Das Sein praktek kehidupan seorang Muslim; etika Islam dan etos kerja seorang Muslim sudah tidak bisa dipisahkan lagi dalam kehidupan beliau.

Pandangan optimistik ini mengandaikan bisa dan mungkin pematrian, setidaknya pemaduan antara Islam doktrin dan Islam peradaban, atau Das Sollen Islam dan Das Sein Islam senyatanya dalam kehidupan kaum Muslimin. Kehidupan Rasulullah adalah uswah atau teladan bagi pengikutnya. Dari alasan demikian, timbullah ketegasan bahwa umat Islam di mana pun bisa menjadi rạ̣matan li al-'ālamīn, sebagaimana Rasulullah telah mencontohkannya. Pandangan optimistik ini dibagi dua golongan, yaitu: golongan yang berkeyakinan bahwa Islam sudah sempurna sebagai petunjuk hidup dunia dan akhirat, dan golongan yang mengatakan bahwa Islam bisa jadi petunjuk akhirat, tetapi untuk urusan-urusan hidup di dunia perlu ada penafsiran-penafsiran yang selalu dipersegar sesuai dengan perkembangan zaman.

Yang terbilang pada pandangan optimistik jenis pertama adalah model aliran revivalis (fundamentalis). Model revivalis atau fundamentalis, garis besar usahanya adalah peduli pada pe- 
YUSUF SUYONO: Menyoal Kesenjangan ...

meliharaan dan penghidupan kembali syariah, kemerdekaan sosial dan politik kaum Muslimin serta menentang norma-norma social Barat dan di sisi lain menunjukkan sikap positif dan tidak peduli terhadap penetrasi sains dan teknologi barat, berbagai lembaga administrasi dan managerialnya serta cara berpikir yang menyertai adopsi teknologi Barat. Pada tradisi intelektual Islam juga mereka abaikan kecuali jika hal itu berkaitan langsung dengan keimanan, persoalan yuridis dan praktek ritual. ${ }^{11}$ Sedangkan yang terbilang pada pandangan yang optimistik jenis kedua adalah model aliran modernis, tradisionalis, bisa jadi juga millenialis. Kelompok dan model modernis berusaha menyajikan intrepretasi dan pemikiran Islam yang modernistic sehingga mampu mengakomodasi gagasan dan ideology Barat. ${ }^{12}$ Di sini bisa dilihat bahwa model modernis tersebut masih memerlukan tafsiran-tafsiran baru termasuk yang diadaptasi dari Barat yang bisa diterapkan pada masyarakat Islam. Mereka disebut aliran adaptasionis. ${ }^{13}$

Lawan dari model modernis adalah aliran tradisionalis. Model aliran tradisionalis juga mencari jawab terhadap tantangan Barat berdasar perspektif intelektual Islam yang sesungguhnya, berusaha mengembalikan kehidupan menurut prinsip-prinsip Islam untuk diterapkan pada kondisi-kondisi kemanusiaan kontemporer tanpa reaksi emosional. Mereke mencoba memikirkan kembali fondasifondasi sains dan teknologi Barat dan juga menghadapi tantangan pemikiran, sains dan teknologi Barat tersebut secara lebih mendalam. Di samping itu, mereka berusaha mempertahankan dan menghidupkan kembali seni Islam beserta prinsip-prinsipnya yang telah tergerogoti selama beberapa decade terakhir akibat serangan gagasan Barat. ${ }^{14}$ Sedang model aliran millenialis meyakini bahwa ketertaklukan Dunia Islam oleh Barat adalah menandakan datangnya pristiwa alam yang bersifat eskatologis yang dalam hal ini hanya dapat dipecahkan oleh pertolongan Allah melalui intervensi-Nya dalam sejarah. ${ }^{15}$ Dengan demikian, model millenialis ini hanya menunggu datangnya sang juru selamat.

TEOLOGIA, VOLUME 25, NOMOR 1, JANUARI-JUNI 2014 
YUSUF SUYONO: Menyoal Kesenjangan ...

Jawaban negatif pessimistik akan menyatakan bahwa hanya Rasulullah yang mampu menyatukan Das Dollen Islam dan Das Sein praksis keislaman Muslim. Sepeninggal beliau, Islam pelan-pelan mulai meninggalkan bumi menuju tempat jauh di langit. Tandatandanya dimulai dari para pembangkang yang kemudian diperangi oleh Abū Bakar dalam perang Riddah; kemudian karut-marut politik yang berakhir dengan terbunuhnya Khalifah ketiga 'Uṡmān ibn 'Affān; diikuti pertikaian-pertikaian pada zaman Khalifah ke empat 'Alī ibn Abī Ṭālib, di mana terjadi perang antara 'Alī dengan Ṭalhahah dan Zubair dari Mekkah yang mendapat dukungan dari 'Āisyah di satu sisi, dan antara 'Alī dengan Mu'āwiyah, di Șiffin Irak di sisi lain yang menjadi noktah hitam sejarah kebudayaan Islam. ${ }^{16} \mathrm{Hal}$ itu berlangsung terus sampai memasuki era pertengahan sejarah Islam, yang merupakan masa kemunduran Dunia Islam, di mana disintegrasi meningkat. Dimulai dari penghancuran Baghdad tahun 1258 M-pusat kekuasaan Dunia Islam Timur-oleh cucu Jengis Khan bernama Hulagu Khan. Di Andalusia (Spanyol), Dunia Islam Barat, Granada kota terakhir kekuasaan Islam di sana, direbut oleh raja Katholik dalam reconquista pada tahun 1491 M. Pada masa kemunduran Dunia Islam ini, yang ada tinggallah etos mengagungkan warisan lama, jargon yang membahana adalah "Pintu Ijtihad tertutup", taqdīs al-fikr al-dīnī (sakralisasi pemikiran keagamaan), sikap romantisis, adab al-Fakhri wa al-Tamjïd (sastra untuk kebanggaan dan pengagung-agungan). ${ }^{17}$ Wajarlah kalau tokoh-tokoh yang lahir pada masa kemuduran Islam ini tidak banyak, dua diantaranya untuk menyebut semua adalah Ibn Taimiyah dan Ibn Khaldūn.

Keadaan seperti ini terus berlanjut sedemikian rupa hingga memasuki abad ke-19, lahirlah para zu'ama' al-Ișlah (para pembaharu) yang mengajak meraih kembali kejayaan Dunia Islam seperti di masa Islam klasik. Dimulai dengan pertanyaan Al-Amir 
YUSUF SUYONO: Menyoal Kesenjangan ...

Syākib Arsalan ( 1869-1946 M) dengan nada pilu, "Limāżā taakhkhar al-Muslimūn wa limāżā taqaddama Ghayruhum?" Sudah dan masih terus banyak yang berupaya menjawab pertanyaan Amir Syākib Arsalan itu, serta berusaha mencari jalan keluarnya.

\section{Usaha-Usaha Para Pemikir memberi Jawaban}

\section{Amir Syākib Arsalan}

Amir Syākib Arsalan sendiri telah menyebut sebab terpuruknya Umat Islam ada enam, yaitu : 1) al-jahl (kebodohan), 2) al-îlm al-nāqiș (ilmu yang kurang/tidak sempurna), 3) Fasād alakhlāq wa lā siyyama akhlāq al-umarā' wa al-ulamā' (dekadensi moral terutama moral para pemimpin dan para ilmuwan), 4) al-ya's wa al-qunūs (putus asa dan putus harapan), 5) nisyān mādihim almājid ( melupakan masa lalunya yang jaya). ${ }^{18}$ Setelah mengajukan sebab-sebab terpuruknya Umat Islam tersebut, Amir Syakib Arsalan memberi jawaban dengan kalimat sebagai berikut :

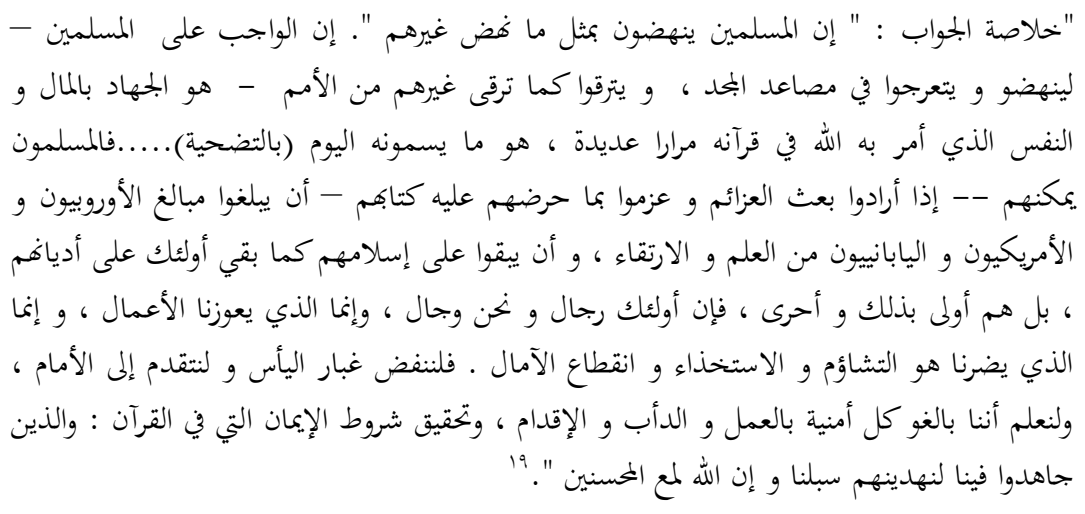

Ringkasan jawaban: "Sesungguhnya kaum Muslimin bisa bangkit seperti umat-umat yang lain". Yang harus dilakukan Umat Islamagar mereka bisa bangkit dan menaiki tangga kejayaan, dan meningkat kemajuannya seperti umat-umat lain-adalah berjuang dengan sungguh-sungguh dengan harta dan jiwa mereka sebagaimana diperintahkan Allah dalam Quran berkali-kali, yaitu apa yang disebut sacrifice (pengorbanan)....Kaum Muslimin sangat mungkin - apabila mereka mau membangkitkan tekad 
YUSUF SUYONO: Menyoal Kesenjangan ...

dan bekerja keras sebagaimana diperintahkan Kitab Suci mereka-mencapai ilmu dan kemajuan seperti yang dicapai bangsa-bangsa Eropa, Amerika, maupun Jepang; dan tetap (percaya diri) pada agama Islam sebagaimana bangsa-bangsa itu tetap pada agama mereka, bahkan lebih baik dari mereka, mereka manusia kita pun manusia; amallah yang menolong kita, dan yang menghalangi kita adalah pessimisme, taqlid buta, serta putus cita-cita. Untuk ituk, buanglah debu-debu keputusasaan dan majulah ke depan; ketahuilah bahwa kita bisa mencapai setiap cita-cita hanya dengan perbuatan (etos kerja), kebiasaan (disiplin), serta keberanian dan mengimplementasikan syaratsyarat iman yang ada dalam Quran: "dan orang-orang yang berjihad untuk (mencari keridaan) Kami, benar- benar akan Kami tunjukkan kepada mereka jalan-jalan kami; dan sesungguhnya Allah benar-benar beserta orang-orang yang berbuat baik" (QS. Al-'Ankabūt [29]: 69).

\section{Syekh Muhammad ‘Abduh}

Ucapan terkenalnya, "Al-Islām mahjūbun bi al-Muslimīn" (keindahan Islam tertutup oleh perilaku umat Islam), menggambarkan dengan jelas kesenjangan Das Sollen Islam dengan das Dein praksis kaum Muslimin. 'Abduh menulis dalam Al-'Urwah alWuśqā dengan judul "Inhițat al-Muslimīn wa Sukūnuhum wa Sabābu Żālik" diawali dengan ayat "Wa'tașimū bi habli Allāhi jamī'an wa lā Tafarraqū". Inti tulisannya itu, antara lain, bahwa kaum Muslimin punya potensi dahsyat dari agamanya yang bisa dibanggakan atas agama-agama lain. Dalam akidah mereka ada factor penyebab paling kuat untuk mengikat persatuan satu sam lain. Namun demikian, saat ini pemeluk agama ini lalai akan potensi ini dan akibatnya sebagian Umat Islam tidak mau tahu apa yang menimpa sebagian yang lain, dan pada gilirannya hilanglah persatuan dan persatuan mereka. Dia mengharap -dalam tulisannya itu-kepada para pemimpin dan ulama untuk berusaha dan bergegas mewujudkan persatuan dan kesatuan umat ini. Di antara baris tulisannya itu adalah sebagai berikut: 
YUSUF SUYONO: Menyoal Kesenjangan ...

ورجاؤنا من ملوك المسلمين و علمائهم من أهل الحمية و الحق أن يؤيدوا هذه الفئة و لا يتوانوا فيما

يوحدوا جمعهم و يجمع شتيتهم

"harapan kami kepada para penguasa-penguasa Muslim dan ulama ahli keadilan dan kebenaran untuk memperkuat umat ini dan jangan bersantai-santai mewujudkan sarana yang bisa memperkuat kesatuan mereka dan mengumpulkan keterserakan mereka." 20

Adapun yang dilakukan 'Abduh untuk pembaharuan Islam dan Umat Islam terbagi dalam tiga isu utama: pertama, membebaskan pikiran dari ikatan taqlid, dan mengajak memahami agama Islam dengan mengikuti ulama-ulama salaf sebelum timbulnya perpecahan-perpecahan. Untuk itu maka umat Islam dalam usaha untuk memahami ajaran Islam harus kembali kepada sumber-sumbernya yang pertama, al-Quran dan al-Sunnah. Kedua, adapun usaha yang kedua adalah memperbaiki bahasa Arab; dan ketiga, memperbaiki pergaulan hidup Umat Islam khususnya bangsa Mesir, dengan menginsafkan pemerintahan dan rakyat tentang hak dan kewajibannya. ${ }^{21}$

\section{Muhammad Iqbal}

Pembaharu Pakistan ini berpendapat bahwa untuk membangun umat, harus dimulai membangun pribadi-pribadi atau individu-individu. Individu-individu Muslim yang diidealkan Iqbal adalah individu yang karena bisa menyerap sebanyak mungkin sifatsifat Tuhan, menjadi individu yang tidak hanya sebagai 'Abd Allāh (hamba Allah) tetapi juga khalīfah Allāh fi al-arḍ. Individu seperti itu adalah individu unggul, pekerja keras dan cerdas serta dapat menentukan nasibnya sendiri saat mana Tuhan menjadi Co-Worker (Mitra-Kerja)-nya. Keadaan ini dijelaskan oleh Cantwell Smith: "Iqbal's God is in the world, now, with us, facing our problems from with, creating a new and better world with us and through us" (Tuhannya Iqbal ada di dunia ini, sekarang, bersama kita menghadapi masalah-masalah kita dari dalam, menciptakan dunia baru 
YUSUF SUYONO: Menyoal Kesenjangan ...

dan lebih baik, dengan kita dan melalui kita).22 Individu khalifah Allāh yang diidealkan Iqbal seperti itu berdialog dengan Tuhan dalam syair berikut :

Thou dids create night and I made the lamps

Thou dids create clay and I made the cup

Thou dids create the deserts, mountains and forests I produced the orchads, gardens and the groves

It is I who turneth stone into a mirror

And it is I who turneth poison into an antidote.

Ya Tuhan, Engkau ciptakan malam, dan akulah yang membuat lampu,

Engkau ciptakan tanah liat, dan akulah yang membuat keramik

Engkau ciptakan padang rumput, gunung-gunung, dan hutanhutan, aku menghasilkan kebun anggur, taman-taman, dan padang tanaman.

Akulah orang yang (harus) merubah batu menjadi sebuah cermin,

Dan akulah orang yang (harus) mengubah racun menjadi obat penawar.

\section{Muḥammad al-Ghazālī}

Ada enam penyebab kemunduran kaum Muslimin sebagaimana diringkaskan oleh Abū Jarrah dari karya Muhammad alGhazālī, dan sebagai pengantar karya dari yang disebut terakhir itu. Enam hal itu disebut sebagai berikut, yaitu : 1) al- Istibdād al-Siyāsī (kediktatoran politik), 2) Fasād al-Tașawwur al-Ijtimā̄î (rusaknya citra masyarakat Islam), 3) Isytighal al-Jahalah wa al-Musya'wiżin bi al-Islām (bermainnya orang-orang bodoh dan penipu dalam Islam), 4) Fitnat al-Nās bi al-Falsafat wa al-Arā' al-Kalāmiyah (ketertarikan manusia (Muslim) dengan filsafat dan pendapat-pendapat (sesat) dalam ilmu Kalam, 5) al-Ghazw al-Śaqāfì bi Syaqqaih al-Ṣālibī alYahūdī wa al-Syuyū'ì al-Ilhādī (serangan budaya dengan dua sisinya: Kristen-Yahudi dan Komunisme-Atheisme), 6) Fuqdān 'Aqīdat alWala' li al-Islām ( Hilangnya akidah fanatisme terhadap Islam). 
YUSUF SUYONO: Menyoal Kesenjangan ...

Setelah menyebut enam faktor penyebab kemunduran dan krisis Umat Islam, Muhammad al-Ghazālī tujuh hal untuk mengentaskan krisis tersebut, yaitu : 1) Darūratu Gharbalati Turās̄ina alDakhm wa Murāja'atuh (pentingnya mengayak/menyaring Turās kita yang begitu besar dan mengulanginya), 2) Dirāsat al-Haḍarat alJadīdah wa Munjazatuhā (mempelajari budaya-budaya baru dan implementasinya), 3) Tahshil al-Hadd al-Adnā min al-Śaqāfah alIslāmiyah bi al-Nisbat li al-Fard (pencapaian batas minimal kebudayaan Islam bagi individu Muslim), 4) Taqdīm al-Islām Kāmilan li al-Nās (Penyajian Islam secara sempurna kepada seluruh manusia), 5) Ijad 'Ulamā' min Tirazin Rafi' (Mewujudkan ulama-ulama tipe unggul), 6) Fiqh al-Ibādah (pemahaman ibadah yang luas), 7) alWaḥdah al-Islāmiyah Tariqīn Tawīl Walakinnahu Darūratu Hayātin (Persatuan Islam Jalan Panjang tetapi merupakan Keniscayaan hidup). ${ }^{23}$

\section{Hassan Hanafi}

Intelektual Mesir ini menyatakan bahwa untuk membangun manusia yang mencakup pertumbuhan ekonomi, yang paling utama adalah membangun kembali (reconstruction) system nilai dan pandangan dunianya. Adalah usaha yang tidak mungkin untuk merelisasikan pertumbuhan ekonomi yang stabil dan permanen tanpa bersamaan dengan usaha membangun kembali konsep budaya masyarakat tentang kerja, produksi, usaha, tujuan, pelayanan, dan sebagainya. Perubahan sosial apapun juga tidak mungkin, apabila tidak ada jaminan pada perubahan simultan dalam pandangan dunia manusia terhadap egalitarianism dan kehidupan masyarakat. Revolusi budaya adalah syarat revolusi politik. Maoisme berhasil adalah karena dia menyempurnakan proses perubahan masyarakat dengan cara menyempurnakan proses rekonstruksi system nilai tradisional (Confucianism) yang parallel sebagai ideologi politik yang membuka jalan bagi pembangunan.

TEOLOGIA, VOLUME 25, NOMOR 1, JANUARI-JUNI 2014 
YUSUF SUYONO: Menyoal Kesenjangan ...

Oleh karena itu, pembangunan pada masyarakat tradisional mengandaikan pengaruh jalan dari agama dan tradsisi popular ini ke edilogi politik. Agama di Dunia Ketiga adalah satu-satunya alat pembawa tujuan-tujuan nasional dan merupakan embrio ideology politik. Rekonstruksi sistem kepercayaan sebagai ideologi politik akan memprotek bangsa-bangsa Dunia Ketiga dari konservatisme tradisional, basis rejim rekasioner, sekularisme yang Western Oriented akibat westernisasi. Rekonstruksi system kepercayaan itu adalah satu-satunya cara, yang dengannya, perubahan social (social change) dapat terjadi secara kontinyu. Identitas bangsa terpelihara melalui perjalanan yang tepat dan disadari dari tradisi ke modernism.

Berikut ini adalah model-model yang direkomendasikan Hassan Hanafi untuk rekosntruksi tersebut :

1. From God to Land (dari Tuhan ke bumi). Percaya pada Tuhan adalah dasar (corner-stone) dari semua sistem kepercayaan. Secara demikian, percaya pada Tuhan berarti bekerja di bumi (ciptaan Tuhan), menghasilkan sesuatu dari bumi, menemukan tambang, pengeboran dan sebaginya. Bumi, kaitannya dengan Tuhan, menjadi bernilai dan berharga. Dengan demikian, pembangunan harus diyakini, kapanpun, sebagai pemenuhan terhadap perintah Tuhan. Bekerja di bumi merupakan satusatunya cara seorang mukmin hidup bersama Tuhan.

2. From Eternity to Time (dari keabadian ke waktu temporal); mudah dalam setiap tradisi menemukan waktu temporal dalam kaitannya dengan yang abadi. Dalam Islam salat berlangsung lima kali sehari, puasa berlangsung pada bulan tertentu (Ramadan) dalam setahun, zakat merupakan kewajiban tiap tahun, haji dilaksanakan pada bulan-bulan tertentu. Pertanyaannya: bagaimana perasaan tentang waktu itu benar-benar direinterpretasikan untuk mendukung 
YUSUF SUYONO: Menyoal Kesenjangan ...

pembangunan? Dapatkah kesan tentang waktu keabadian ditransformasikan ke kesan waktu bagi petani di sawah atau pekerja di pabrik mereka?

3. From Predestination to Free Will (Dari Jabariah ke Qadariyah). Di Negara-negara yang belum berkembang, kurangnya Free Will dan supremasi Jabariah adalah salah satu penyebab ketatnya birokrasi dan sentralisasi. Memberi prioritas penuh kepada Free Will pa tradisi-tradisi tertentu bisa jadi sangat menguntungkan untuk pembangunan. Dalam Islam, tanggung jawab individu sangat ditekankan. Manusia dilahirkan bebas dari dosa dan tidak memerlukan penyelamatan eksternal. Manusia adalah wakil Tuhan di bumi yang memenuhi kehendak-Nya dan melaksanakan muatan (isi) wahyu sebagai struktur ideal dunia ini.

4. From Authority to Reason (dari otoritas ke akal). Pertentangan antara keduanya terus berlangsung. Di negara-negara yang belum berkembang, otoritarianismelah yang menang. Hampir semua keputusan-keputusan penting bidang potik, social, ekonomi dibuat dari "atas" (yang punya otoritas). Elit yang berkuasa adalah "dynamo" dan pusat segala pembuatan keputusan. Sebaliknya, planning, satu jalan menuju pembangunan tidak dapat hanya didasarkan pada argument dari otoritas. Planning harus didasarkan pada analisa, statistik dan tujuan-tujuan yang tidak dapat dicapai kecuali lewat argument-argumen akal. Di Negara-negara yang belum berkembang, pembangunan menderita kekurangan planning karena kurangnya rasionalisasi dalam hidup. Islam, sebagai agama yang tidak kenal sesuatu yang misteri dan otoritas, akan mengijinkan dengan mudah penggunaan akal ini. Akal adalah seimbang dengan wahyu, dan keduanya adalah sama terhadap Tuhan.

TEOLOGIA, VOLUME 25, NOMOR 1, JANUARI-JUNI 2014 
YUSUF SUYONO: Menyoal Kesenjangan ...

5. From Theory to Action (dari teori ke aksi). Adalah sudah dimaklumi bahwa ideology Dunia Ketiga tentang pembangunan membawa banyak slogan tetapi tanpa implemntasi. Setiap pemimpin adalah teorisi. Problem-problem dan isu-isu riel ditangani dengan kurang perhatian dan produksi menjadi stagnan. Dalam Islam, perbuatan yang baik adalah manifestasi dari iman. Iman tanpa perbuatan adalah nol dan hampa. Perbuatan benar yang berdasar pada teori yang salah adalah lebih bernilai ketimbang teori yang benar tetapi tanpa aksi apapun. Aksi salah berdasar pada teori yang benar adalah lebih baik dari teori yang benar tetapi tanpa aksi.

6. From Charisma to Mass-participation (dari karisma ke partisipasi massa). Dalam Islam, spirit jama'ah adalah inti dari Islam. Salat jamaah lebih baik dari salat sendirian. Tujuan puasa adalah agar merasakan kehadiran orang lain. Haji bisa bermakna ganda sebagai rapat tahunan bagi planing masyarakat. Nilai seorang mukmin adalah pada partisipasinya dalam hidup bermasyarakat.

7. From Soul to Body (dari jiwa ke badan). Badan adalah fana sedang jiwa (ruh) adalah abadi. Karena seorang beriman yang ditunju adalah kehidupan abadi, maka dia tidak menggapai yang dituju itu kecuali melalui jiwa (ruh) yang bersifat abadi itu. Dengan demikian, bagi kepercayaan tradisional, pembangunan adalah hanyalah pencucian jiwa. Pembangunan spiritual adalah alternatil tradisional bagi pembangunan material.

8. Karena problem di Dunia Ketiga adalah pembangunan global, termasuk pembangunan material, maka perubahan konsentrasi dari jiwa ke badan adalah suatu kebutuhan dalam budaya massa. Dalam Islam, penekanan diletakkan pada 
YUSUF SUYONO: Menyoal Kesenjangan ...

pentingnya badan dan dunia. Dengan demikian. Pembangunan menjadi mungkin melalui persepsi badan.

9. From Eschatology to Futurology (dari eskatologi ke masa depan). Eskatologi sungguh memainkan peran teleology dalam kesadaran manusia. Teologi dalam filsafat adalah sumber futurology dalam ilmu-ilmu manusia. Karena pembangunan membutuhkan planning, dan planning membutuhkan konsep masa depan maka perjalanan dari eskatologi ke futurology dalam setiap tradisi keagamaan di Negara-negara berkembang menjadi perlu. Eskatologi berarti masa depan manusia dan masa depan dunia. Manusia harus mempersiapkan diri untuk masa depan yang lebih baik dan untuk membuat dunia ini sebaik mungkin bahkan terbaik. Dunia ini mengandung telos (tujuan) imanen di dalamnya, yaitu from yang baik ke yang lebih baik, ke yang terbaik meminjam istilah teologi Mu'tazilah al-Shalah wa al-Ashlah. ${ }^{24}$

Itulah keprihatinan para pemikir jamahir (Mufakkir Jamāhir) atas kesenjangan antara Das Sollen Islam sebagai ajaran, dan Das Sein praksis kaum Muslimin di atas panggung historisnya di muka bumi ini. Keprihatinan itulah yang mendorong mereka mencari jalan keluar agar menjembatani kesenjangan (to bridge the gap) antara Das Sollen Islam dan Das Sein Umat Islam dengan mengajukan beragam rekomendasi untuk solusi Umat.

Khusus untuk Indonesia, semua organisasi-apalagi yang lahir sebelum negeri ini lahir-terutama NU dan Muhammadiyah, telah berupaya keras untuk kejayaan kaum Muslimin agar sejalan dengan kehebatan Islam. Semuanya bertujuan izzatul Islām wa al-Muslimīn. Pendiri kedua oraganisasi tersebut, karena jasanya, ditetapkan sebagai pahlawan Nasional. Khusus dengan Indonesia saat ini, Muhyar Fanani dalam sebuah penelitiannya menyebutkan bahwa sebelum mengkategorikan Indonesia Negara maju atau tidak, dalam 
YUSUF SUYONO: Menyoal Kesenjangan ...

penelitiannya, beliau menyebut empat indikator. Pertama, dari sisi individu masyarakatnya, mempunyai etos kerja yang tinggi, ulet, pekerja keras, berorientasi kepada hasil pekerjaan, mempunyai sikap dan pikiran terbuka, rasional, dan tak terkait dengan nilai-nilai tradisional. Kedua, dari sisi sosial, muncul spesialisasi dan fungsifungsi tiap anggota masyarakat dalam segala aspek kehidupan. Pada gilirannya ini akan menimbulkan kelas-kelas social dan ekonomi baru. Ketiga, dari sisi managemen negara, politik, dan hokum, muncul tata kelola pemerintahan yang teratur dan bersih, partisipasi aktif warga dalam perpolitikan nasional, adanya check and balances dari warga kepada Negara, dan adanya ketaatan kepada hukum. Keempat, dari sisi ekonomi, industrialisasi secara massif, terbuka terhadap investasi asing dan perdagangan dengan dunia luar, serta penggunaan peralatan berteknologi canggih dalam kehidupan sehari-hari masyarakatnya. ${ }^{25}$

Dari keempat kriteria Negara maju tersebut, Muhyar Fanani menyatakan bahwa dalam beberapa segi Indonesia telah mencapainya, namun dalam banyak bidang yang lain harus berusaha lebih giat lagi. Beberapa contoh diungkapkannya. Di bidang teknologi, Indonesia lebih banyak berperan sebagai pengguna daripada produsen. Di bidang perekonomian, Indonesia yang cukup bagus dan aman ternyata tak memberikan dampak secara nyata terhadap kemakmuran rakyat. Kekayaan alam dan kemajuan ekonomi hanya dinikmati sebagian kecil masyarakat Indonesia, sefdang mayoritas rakyat masih hidup miskin dan menderita. Setelah panjang lebar membeberkan contoh-contoh ketidakidealan menjalankan amanah dalam berbagai bidang, beliau berkesimpulan bahwa Indonesia belum bisa disebut negara maju. ${ }^{26}$

Menurut Muhyar Fanani, perilaku-perilaku manusia Indonesia yang tidak ideal di atas, adalah karena penyimpang dari epistemologi budi. Dengan demikian, untuk menuju Indonesia berkemajuan, 
YUSUF SUYONO: Menyoal Kesenjangan ...

manusia Indonesia -terutama yang diberi amanah mengelolanya-harus mengaplikasikan epistemologi budi. Hal itu dikarenakan : a) Epistemologi budi mempersyaratkan perpaduan yang seimbang antara akal dan rasa sukma yaitu rasa ketuhanan (roso njero), bukan rasa ragawi (roso njobo), b) Epistemologi budi tumbuh dalam bentuk tindakan dan bukan wacana, c) Epistemologi budi akan menghasilkan karakter masyarakat yang positif, seperti : kreatif, ramah, gotong royong, dan kekeluargaan, d) Epistemologi budi tidak menafikan modernitas yang bercirikan rasionalitas, tetapi juga harus tidak menolak tradisi, norma, dan ajaran agama. ${ }^{27}$

\section{E. Penutup}

Demikianlah potret kaum Muslimin yang jauh dari idealitas yang diajarkan oleh Islam, agama yang dianutnya. Keadaan demikian itu akan mengundang banyak pertanyaan para pemerhati. Apakah Islam sebagai agama yang telah disempurnakan Allah, tidak applicable di muka bumi ini? Apakah agama yang baik itu tidak bisa mewarnai perilaku pemeluknya? Apakah Islam yang dimaksud Allah dan Rasul-Nya berbeda dengan Islam yang kita pahami? Apakah keterpurukan Umat Islam itu memang sebagai sunnatullah sebagai perwujudan dari "wa tilka al-ayyāmu nudawiluhā ban al-Nās?" Mengapa agama-agama lain bisa berpengaruh pada pemeluknya sehingga mereka maju?

Ajaran Beruf dari Calvinisme salah satu aliran Protestan bisa menjadi pendorong etos kerja keras yang menjadi modal dasar lahirnya semangat kapitalisme di Eropa Barat dalam penelitian Max Weber. ${ }^{28}$ Ajaran Buddha Zen telah bisa memicu etos kerja Orang Jepang. Menurut Suzuki Shoshan, pendeta Buddha Zen, untuk membangun kembali masyarakat, hati manusia perlu dilindungi dari tiga penyakit, yaitu ketamakan, kemarahan, dan ketidakpuasan. Untuk itu, seseorang harus menjadi Buddha, yakni hidup sesuai 
YUSUF SUYONO: Menyoal Kesenjangan ...

dengan hati nuraninya. Hal itu memerlukan latihan dengan melibatkan diri dalam hidup yang saleh. Praktek hidup saleh bagi orang biasa bukan pendeta adalah harus bekerja keras dan terus menerus tak henti-hentinya mencari penghidupan. Dengan niat yang benar, maka setiap gerak kerja dapat dinilai Buddhis. Inilah dasar-dasar etika social Zen yang pengaruhnya tidak saj terbatas pada lingkungan agama, tetapi juga menjangkau ke masyarakat luas. Hal itu menurut penelitian Sarjana Injil Yamamoto Shichihei. ${ }^{29}$ Agama dan filsafat Kong $\mathrm{Hu} \mathrm{Cu}$ juga telah berpengaruh positif pada kemajuan Korea. Disebut dalam penelitian Dipo Alam, bahwa sebabsebab kemajuan Korea adalah : a) dilakukannya strategi pembangunan "Outward Looking Oriented" sejak tahun 1962, b) kondisi perekonomian yang favorable, c) tingginya tingkat penduduk dalam mendapatkan pendidikan karena inheren dengan kebudayaan Korea yang banyak dipengarui filsafat Confucian (Kong $\mathrm{Hu} \mathrm{Cu})^{30}$

Banyaknya pertanyaan tersebut diatas, bukan sedang ingin menertawakandiri sendiri, atau membuka borok sendiri. Hal ini justru sedang dalam usaha mengamalkan ajaranRasul " Thuba liman syaghalahu 'aibuhu 'an 'Uyuubi al-Nas " (Adalah baik sekali, orang yang disibukkan dengan ngurusi aibnya sendiri ketimbang ngurusi aib orang lain). Ketimbang menyalahkan kelompok lain seperti Yahudi-Nasrani, dan ketimbang menyalahkan kolonialisme yang sudah lama berlalu, alangkah baiknya apabila menyingkap kesalahan kita sendiri untuk kemudian kita melesat ke depan.

Pertanyaan-pertanyaan tersebut harus diupayakan menjawabnya terutama oleh para ilmuwan Muslim, yang selain mempunyai tanggung intelektual tetapi juga tanggung moral dan sosial terhadap masyarakatnya. Membiarkan pertanyaan-pertanyaan seperti itu tanpa jawaban, sama artinya membiarkan semakin lebarnya Das Solen Islam sebagai ajaran, petunjuk Ilahi dengan Das Sein praktek kaum Muslimin -Pemeluknya. Akibatnya bisa hilangnya trust pada agama ini yang berbentuk Leaving Islam, 
YUSUF SUYONO: Menyoal Kesenjangan ...

dari yang ringan seperti phobia, agnostisisme, hipocricy; atau yang lebih berat seperti riddah (apostasy) baik Murtadd Fitri maupun Murtadd Milli. Pola pikir dan pola tingkah model al-Rawandī danalRāzī, serta Ibn Warraq adalah contohnya di Dunia Islam. Sedangkan ucapan Sigmund Freud, "...religion as a universal obsessional neurosis (...agama adalah neurosis [penyakit mental] kolektif )”, dan Karel Marx, "Agama adalah candu masyarakat", atau A.N. Wilson, "Against Religion: Why we should live without it?" adalah contoh figur-figur di Barat yang kehilangan trust pada agama. []

\section{Catatan Akhir}

${ }^{1}$ Musa Asy'arie, Filsafat Islam : Sunnah Nabi Dalam Berpikir, Yogyakarta: LESFI, 2002, h. 6

${ }^{2}$ Sir Mohammd Iqbal, The Reconstruction of Religious Thought in Islam, London: Humphrei Milford, 1932, h. 3.

IIbid., h. vi.

${ }^{4}$ Harry Hamersma, Pintu Masuk ke Dunia Filsafat, Yogyakarta: Kanisius, 2008, h. 9-10.

5http://bisniskeuangan.kompas.com/read/2013/11/22/112638

0/Ini.Daftar.Orang.Terkaya. di.Indonesia.Tahun.2013). 6http://www.kaskus.co.id/thread/52546124be29a025728b456

9/20-peringkat-indonesia-di-dunia-tahun-2013.

7http://www.bimba-aiueo.com/kenapa-minat-baca-di-

indonesia-rendah.

${ }^{8}$ Al-Amir Syākib Arsalan, Limāżā Taakhkhara al-Muslimūn wa Limāżā Taqaddama Ghayruhum, Kairo: Dār al-Basyīr li al-Ṭibā'ah wa alNasyr wa al-Tawzi', tth, h. 91.

${ }^{9}$ Suara Muhammadiyah No 21 TH ke 98, Nopember 2013: 10.

10Ibn Warraq, Leaving Islam: Apostates Speak Out, New York: Promethus Books, 2003, h. 203.

${ }^{11}$ Seyyed Hossein Nasr, Menjelajah Dunia Modern, Bandung: Mizan, 1995, h. 131.

12Ibid.

13John Obert Voll, Islam: Continuity and Change in the Modern World, England: Longman Group, 1982, h. 97.

TEOLOGIA, VOLUME 25, NOMOR 1, JANUARI-JUNI 2014 
${ }^{14}$ Seyyed Hossein Nasr, Menjelajah, h. 134.

15 Ibid.

16Harun Nasution, Islam Ditinjau Dari Berbagai Aspeknya, Jakarta: UI Press, 1985, h. 93-94.

17Muhammad Quraish Shihab, Membumikan Al-Qur'an, Bandung: Mizan, 1992, h. 52.

${ }^{18} \mathrm{Al}$-Amir Syakib Arsalan, Limāżā, h. 75-76.

19Ibid., h. 163-164.

20Jamāl al-Dīn Al-Afghanī dan Syekh Muhammad 'Abduh, Al'Urwah al-Wuśqā, Beirūt: Dār al-Kitāb al-'Arabī, 1970, h. 70-75.

${ }^{21}$ H.A. Mukti Ali, Ijtihad Dalam Pandangan Muhammad Abduh, Ahmad Dahlan, dan Muhammad Iqbal, Jakarta: Bulan Bintang, 1990, h. 36.

${ }^{22}$ Yusuf Suyono, Reformasi Teologi: Muhammad Abduh vis a vis Muhammad Iqbal, Semarang: RaSAIL, 2008, h. 143.

${ }^{23}$ Muhạmmad al-Ghazālī, Sirr Takhkhur al-'Arab wa al-Muslimīn, Kairo : Dār al-Rayan li al-Turāś, 1987, h. 11-18.

${ }^{24}$ Hassan Hanafi, Islam In the Modern World: Religion, Ideology, And Development, Vol. I, Kairo: The Anglo-Egyptian Bookshoop, 1995, h. 7-15.

25Muhyar Fanani, Epistemologi Budi Sebagai Epistemologi Khas Indonesia dalam Perspektif Epistemologi Islam, Semarang: Lembaga Penelitian IAIN Walisongo, 2012, h. 206-207.

26Ibid., h. 210.

27Ibid., h. 216- 252.

${ }_{28}$ Taufik Abdullah (ed.), Agama, Etos Kerja dan Perkembangan Ekonomi, Jakarta: LP3ES, 1979, h. 4.

${ }^{29}$ M. Dawam rahardjo, "Budhisme Zen Dan Etos Kerja Jepang" dalam Ulumul Qur'an No. 2, Juli-September 1989, h. 39.

30Dipo Alam, "Mengapa Korea Maju ?" dalam Panji Masyarakat No. 605, Februari 1989, h. 28. 


\section{DAFTAR PUSTAKA}

Afghan̄ī Jamāl al-Dīn, dan Syekh Muhammad 'Abduh, al-'Urwat al-Wuśqā, Beirūt: Dār al-Kitāb al-'Arabī, 1970.

Ali, A. Mukti, Ijtihad Dalam Pandangan Muhammad Abduh, Ahmad Dahlan, dan Muhammad Iqbal, Jakarta: Bulan Bintang, 1990.

Arsalan, Al-Amir Syākib Limāżā Ta'khkhara al-Muslimūn wa Limāżāa Taqaddama Ghayruhum, Kairo: Dār al-Basyīr li al-Ṭiba'ah wa alNasyr wa al-Tawzì', tth.

Asy'arie, Musa, Filsafat Islam: Sunnah Nabi Dalam Berpikir, Yogyakarta : LESFI, 2002.

Fanani, Muhyar, Epistemologi Budi Sebagai Epistemologi Khas Indonesia dalam Perspektif Epistemologi Islam, Semarang : Lembaga Penelitian IAIN Walisongo, 2012.

Ghazālī, Muhammd, Sirr Takhkhur al-'Arab wa al-Muslimīn, Kairo: Dār al-Rayan li al-Turāṡ, 1987.

Hanafi, Hassan, Islam In the Modern World, Vol. I : Religion, Ideology, And Development, Cairo : The Anglo-Egyptian Bookshoop, 1995.

Ibn Warraq, Leaving Islam : Apostates Speak Out, New York : Promethus Books.

Iqbal, Sir Mohammd, The Reconstruction of Religious Thought in Islam, London: Humphrei Milford, 1932.

Nasr, Seyyed Hossein, Menjelajah Dunia Modern, Bandung : Mizan, 1995.

Nasution, Harun, Islam Ditinjau Dari Berbagai Aspeknya, Jakarta: UI Press, 1985.

Panji Masyarakat No. 605, Februari 1989.

Shihab, Muhammad Quraish, Membumikan Al-Qur'an, Bandung: Mizan, 1992.

TEOLOGIA, VOLUME 25, NOMOR 1, JANUARI-JUNI 2014 
Suara Muhammadiyah, No 21 TH ke 98, Nopember 2013.

Suyono, Yusuf, Reformasi Teologi : Muhammad Abduh vis a vis Muhammad Iqbal, Semarang: RaSAIL, 2008.

Taufik Abdullah (ed.), Agama, Etos Kerja dan Perkembangan Ekonomi, Jakarta: LP3ES, 1979.

Voll, John Obert, Islam : Continuity And Change in the Modern World, England: Longman Group, 1982. 